\title{
Analisis Hambatan Penggunaan Hydrofoil pada Katamaran Menggunakan CFD
}

\author{
Regi Yudha Dikantoro, I Ketut Suastika, dan Dedi Budi Purwanto \\ Departemen Teknik Perkapalan, Fakultas Teknologi Kelautan, Institut Teknologi Sepuluh Nopember \\ (ITS) \\ e-mail:k_suastika@na.its.ac.id
}

\begin{abstract}
Abstrak-Simulasi CFD dilakukan untuk mempelajari pengaruh hydrofoil dan pemasangan hydrofoil secara memanjang terhadap hambatan HYSUCAT. Tiga variasi penempatan foil dilakukan yaitu (i) posisi 1 :dibawah center gravity kapal, (ii) 3 panjang chord ke arah stern dari posisi 1 , dan (iii) 6 panjang chord ke arah stern dari posisi 1. Pada kecepatan relatif rendah (FnV < 1,8), hydrofoil menambah hambatan katamaran. Sebaliknya pada kecepatan relatif tinggi $(\mathrm{FnV}>1,8)$, hydrofoil mengurangi hambatan katamaran. Nilai koefisien hambatan meningkat pada awalnya, mencapai nilai maksimum kemudian berkurang seiring meningkatnya bilangan Froude. Nilai maksimum terjadi pada $\mathrm{FnV} \approx 1.4$ (atau $\mathrm{Fn} \approx 0,5$ ). Posisi peletakkan foil yang paling optimum adalah dibawah CG kapal.
\end{abstract}

Kata Kunci-CFD, Hambatan Kapal, Hydrofoil, Hysucat, Katamaran.

\section{PENDAHULUAN}

A PLIKASI kapal katamaran sebagai moda transportasi atau angkutan laut/ sungai telah berkembang secara pesat dewasa ini dan nampaknya akan terus berkembang dimasa akan datang. Drewry Shipping Consultans, Ltd., (1990) menyatakan bahwa $43 \%$ dari seluruh armada angkutan penumpang dan kendaraan yang ada dewasa merupakan kapal tipe katamaran.

Suatu hal yang membuat kapal katamaran menjadi populer dan sukses digunakan sebagai moda transportasi adalah tersedianya area geladak (deck area) yang lebih luas dan tingkat stabilitas yang lebih nyaman dan aman [1]. Disamping itu katamaran (lambung ganda) dengan bentuk badan yang langsing dapat memperkecil timbulnya sibakan air dibanding kapal lambung tunggal.

Penggunaan hydrofoil pada kapal telah banyak dilakukan karena menawarkan kelebihan yaitu mengurangi hambatan yang dihasilkan akibat adanya gaya angkat (lift) yang mengangkat badan lambung kapal diatas air sehingga memperkecil luas hambatan yang terjadi akibat gaya gesek (drag) antara lambung kapal yang tercelup air.

Munculah ide mengombinasikan hydrofoil pada katamaran yang diwujudkan dalam kapal HYSUCAT (Hydrofoil Supported Catamaran). HYSUCAT adalah kapal hybrid yang mengabungkan pengunaan hydrofoil pada kapal katamaran. Kapal jenis ini memiliki efsiensi yang lebih besar dibandingkan dengan kapal cepat atau jenis katamaran dengan bentuk lambung v. HYSUCAT menunjukkan pengurangan pada tenaga propulsi dan memiliki karakteristik seakeeping yang baik pada rough water [2].

Pada Penelitian ini dilakukan untuk mengetahui penagaruh penambahan foil pada lambung kapal katamaran terhadap hambatan kapal yang dihasilkan.

\section{TINJAUAN PUSTAKA}

\section{A. Kapal Katamaran}

Kapal Katamaran merupakan kapal dengan lambung ganda (Twin Hull) sehingga, dimana kedua lambung tersebut dihubungkan dengan konstruksi geladak yang kuat dan merentang di atasnya untuk menahan momen bending (bending moment) dan gaya geser (shear force) yang besar dan bekerja terhadap garis tengah (Centre line).

Terdapat berbagai macam bentuk lambung kapal katamaran namun secara umum bentuk lambung kapal katamaran terbagi menjadi tiga macam yaitu:

1. Simetris

2. Asimetris dengan bagian lurus dalam (flat inside)

3. Asimetirs dengan bagian lurus luar (flat outside)

\section{B. Hysucat}

HYSUCAT (Hydrofoil Support Catamaran) adalah kapal hybrid yang menggunakan hydrofoil untuk menghasilkan gaya angkat dengan tujuan mengurangi hambatan yang dihasilkan. Hysucat menggunakan hydrofoil didalam terowongan antara dua demihull katamaran.

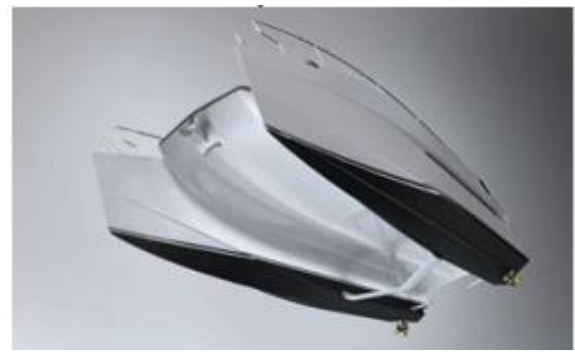

Gambar 1. Hysucat

Secara umum jenis kapal Hysucat menggunakan sebuah foil diletakkan di posisi LCG kapal dan membentang pada celah antara demihull. Pada kecepatan tinggi, Hydrofoil yang didesain mengangkat demihull keluar dari air. Hal ini tejadi karena gaya angkat yang dihasilkan lambung kapal lebih kecil dan dynamic planning force lebih dominan.

Pada umumnya jenis kapal katamaran dengan mono foil sangat sensitif terhadap perubahan LCG kapal serta 
memerlukan sebuah trim device untuk pengoperasiannya. Untuk mengatasi permasalahan tersebut digunakan sistem dua foil. Foil utama diletakkan sedikit didepan posisi LCG kapal dan trim foil dipasang dekat transom dengan posisi diatas keel supaya foil beroperasi pada permukaan air. Foil utama mengangkat sekitar $40-75 \%$ berat kapal pada kecepatan desain tergantung ukuran dan displasemen kapal [3].

Pengurangan hambatan kapal katamaran akan terjadi ketika hydrofoil yang berada didalam terowongan dua demihull mengangkat sebagian berat kapal pada kecepatan tertentu sehingga badan kapal terangkat keluar dari air yang berdampak pada berkurangnya hambatan karena hydrofoil mempunyai efisiensi gaya angkat yang lebih besar dibandingkan lambung.

\section{NACA Foil Series}

NACA (National Advisory Committee for Aeronautics) airfoil adalah salah satu bentuk bodi aerodinamika sederhana yang berguna untuk dapat memberikan gaya angkat tertentu terhadap suatu bodi lainnya dan dengan bantuan penyelesaian matematis sangat memungkinkan untuk memprediksi berapa besarnya gaya angkat yang dihasilkan oleh suatu bodi airfoil. Geometri airfoil memiliki pengaruh besar terhadap karakteristik aerodinamika dengan parameter penting berupa $\mathrm{CL}$, dan kemudian akan terkait dengan lift (gaya angkat yang dihasilkan).

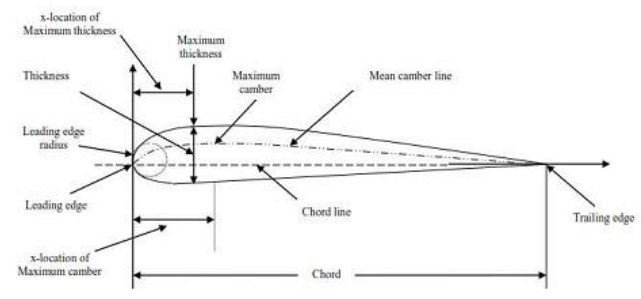

Gambar 2. NACA Airfoil geometri

Hingga sekitar Perang Dunia II, airfoil yang banyak digunakan adalah hasil riset. Selama periode ini banyak pengajuan airfoil dilakukan diberbagai negara, namun hasil riset, NACA-lah yang paling terkemuka. Pengujian yang dilakukan NACA lebih sistematik dengan membagi pengaruh efek kelengkungan dan distribusi ketebalan atau thickness serta pengujiannya dilakukan pada bilangan Reynold yang lebih tinggi dibanding yang lain. Hal ini sering dirangkum oleh beberapa parameter seperti: ketebalan maksimum, maksimum bentuk melengkung, posisi maksimal ketebalan, posisi maksimal bentuk melengkung, dan hidung jari-jari [4]. Seperti terlihat suatu airfoil terdiri dari:

- Permukaan atas (Upper Surface)

- Permukaan bawah (Lowerer Surface)

- Mean camber line adalah tempat kedudukan titik-titik antara permukaan atas dan bawah airfoil yang diukur tegak lurus terhadap mean camber line itu sendiri.

- Leading edge adalah titik paling depan pada mean camber line, biasanya berbentuk lingkaran dengan jarijari mendekati $0,02 \mathrm{c}$.

- Trailing edge adalah titik paling belakang pada mean camber line
- Camber adalah jarak maksimum antara mean camber line dan garis chord yang diukur tegak lurus terhadap garis chord.

- Ketebalan (thickness) adalah jarak antara permukaan atas dan permukaan bawah yang diukur tegak lurus terhadap garis chord.

\section{Hambatan Kapal}

William Froude (1867) pertama kali memperkenalkan total hambatan kapal yang terdiri atas dua komponen yaitu hambatan sisa (residual) dan hambatan gesek (friction). Hambatan sisa dalam hal ini meliputi komponen hambatan wave-making system energies, eddy dan viscous energy losses akibat bentuk lambung kapal. Sedangkan hambatan gesek kapal diasumsikan sama dengan hambatan gesek suatu pelat datar 2-dimensi yang mempunyai luas permukaan bidang basah yang sama serta bergerak di air pada kecepatan sama dengan kecepatan kapal.

Komponen hambatan total pertama kali diperkenalkan oleh W. Froude. Dimana hambatan total merupakan penjumlahan hambatan gesek (RF) dengan hambatan sisa (RR) sehingga didapat persamaan:

$$
R_{T}=R_{F}+R_{R}
$$

Dimana :

$R_{T}$ : Hambatan total kapal

$R_{F}:$ Hambatan gesek

$R_{R}$ : Hambatan sisa

Metode analisa 2-dimensi tersebut diatas tidak cukup mengrefleksikan kontribusi bentuk/kontur lambung kapal (yang 3dimensi) terhadap hambatan viskos, sehingga kemudian (Hughes, 1954)memperkenalkan metode untuk digunakan dalam korelasi model kapal dimana total hambatan adalah penjumlahan dari 3 (tiga) komponen:

1. Hambatan gesek (friction) adalah gaya tangential stress yang timbul antara molekul air dan kulit badan kapal, yang kemudian sebagai hambatan bidang permukaan dengan area dan panjang yang sama dengan model.

2. Hambatan bentuk (form) adalah komponen hambatan yang dinyatakan dalam bilangan ' $\mathrm{k}$ ', dimana merupakan hambatan diluar batas item diatas dalam kasus lambung yang tercelup cukup dalam. Hughess mengasumsikan bahwa untuk lambung yang streamline pada aliran turbulent, dapat diekspresikan sebanding dengan hambatan friction.

3. Hambatan free surface sebagai hambatan gelombang $(C W)$ adalah hambatan yang timbul akibat pergerakan kapal relatif terhadap air sehingga timbul perbedaan tekanan pada permukaan (bidang) basah kapal yang selanjutnya menimbulkan wave pattern. Hambatan gelombang merupakan pengurangan total hambatan $(C T)$ dari penjumlahan hambatan gesek $(C F)$ dan hambatan bentuk $\left(\mathrm{CF}_{0}\right)$ dari model.

\section{Metodologi Penelitian}

\section{A. Model kapal dan foil}

Model kapal yang digunakan adalah kapal yang didesain pada jurnal yang memiliki ukuran utama sebagai berikut: 
Tabel 1.

Ukuran Utama Kapal

\begin{tabular}{lc}
\hline \hline Dimensi Partikular & Kapal \\
\hline LWL & $44,00 \mathrm{~m}$ \\
$\mathrm{~B}$ & $11,80 \mathrm{~m}$ \\
$\mathrm{~T}$ & $1,40 \mathrm{~m}$ \\
$\mathrm{H}$ & $3,80 \mathrm{~m}$ \\
$\mathrm{Vs}$ & $28 \mathrm{knot}$ \\
$\mathrm{B}_{1}$ & $3,00 \mathrm{~m}$ \\
\hline \hline
\end{tabular}
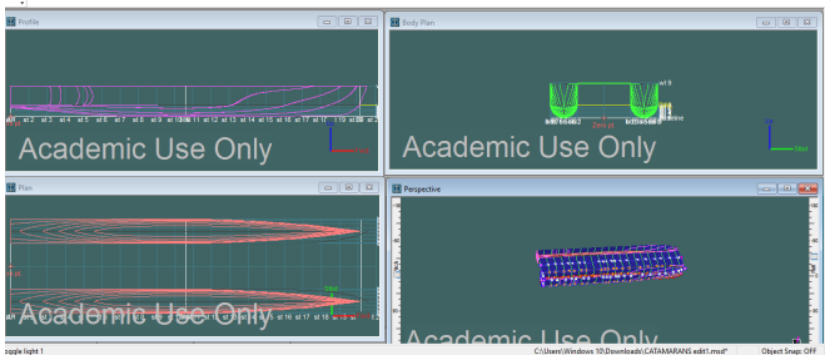

Gambar 3. Model Kapal

Foil yang digunakan adalah NACA 64A1212 dan strut yang digunakan adalah NACA 0010. Ukuran foil yang digunakan dianalisa lift/drag pada berbagai aspek rasio.

Tabel 2.

Perbandingan lift/drag terhadap aspek rasio

\begin{tabular}{ccccccc}
\hline \hline No & chord(m) & $\begin{array}{c}\text { Span } \\
(\mathbf{m})\end{array}$ & $\begin{array}{c}\text { aspek } \\
\text { ratio }\end{array}$ & $\begin{array}{c}\text { Drag } \\
(\mathbf{N})\end{array}$ & Lift (N) & L/D \\
\hline 1 & 0,8 & 5,2 & 6,5 & 2006,6 & 18289,3 & 9,114 \\
2 & 1 & 5,2 & 5,2 & 2780,9 & 21947,2 & 7,892 \\
3 & 1,2 & 5,2 & 4,333 & 3159 & 25179,3 & 7,971 \\
\hline \hline
\end{tabular}

Dari Tabel 2 diketahui bahwa lift/drag yang digunakan untuk dipasang pada katamaran adalah foil yang memiliki aspek rasio 6,5. Sedangkan ukuran strut yang memiliki chord yang sama dengan foil dan span $2,8 \mathrm{~m}$. Setelah menentukan ukuran, tahapan selanjutnya menentukan sudut serang yang optimum.

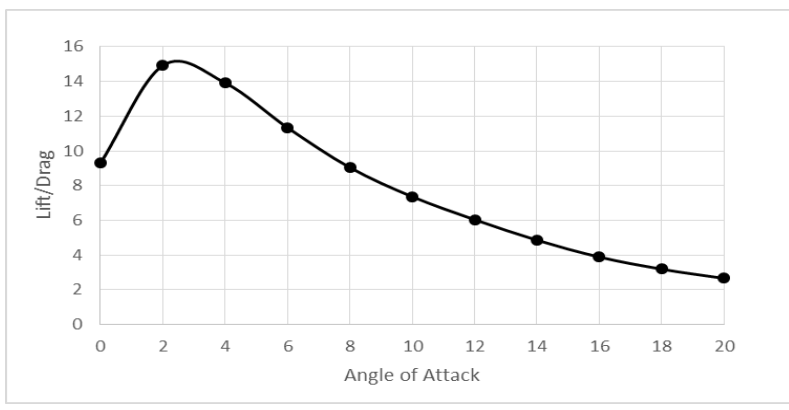

Gambar 4. L/D ratio berbagai sudut serang.

Gambar 4 menunjukkan perbandingan antara lift force/drag force yang dialami foil pada berbagai variasi sudut serang dimana lift forcel drag force mengalami stall pada sudut serang $2^{\circ}$.

Foil diletakan pada kedalaman 0.4 meter dari permukaan air.Pemasangan foil pada katamaran yang divariasikan dengan mengubah posisi foil secara memanjang yaitu posisi foil di $\mathrm{cg}$ kapal, posisi foil $3 \mathrm{c}$ ke arah stern dan posisi foil 6c kearah stern. Variasi pemasangan foil dapat dilihat pada gambar
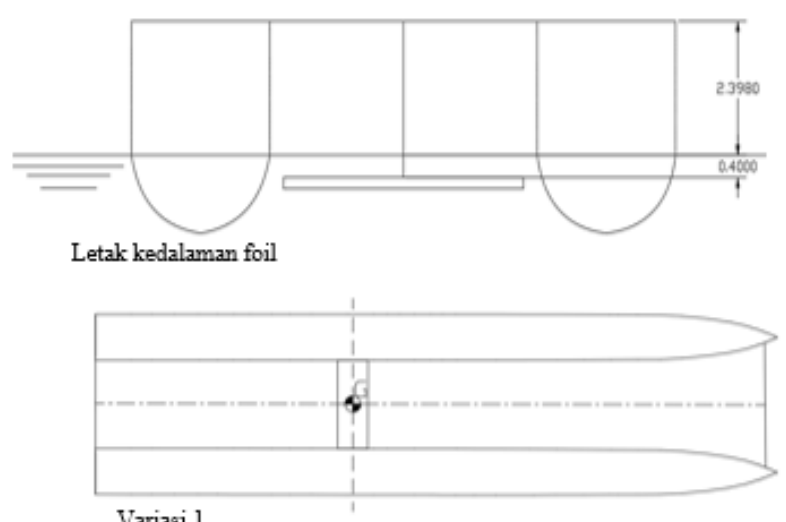

Variagi l
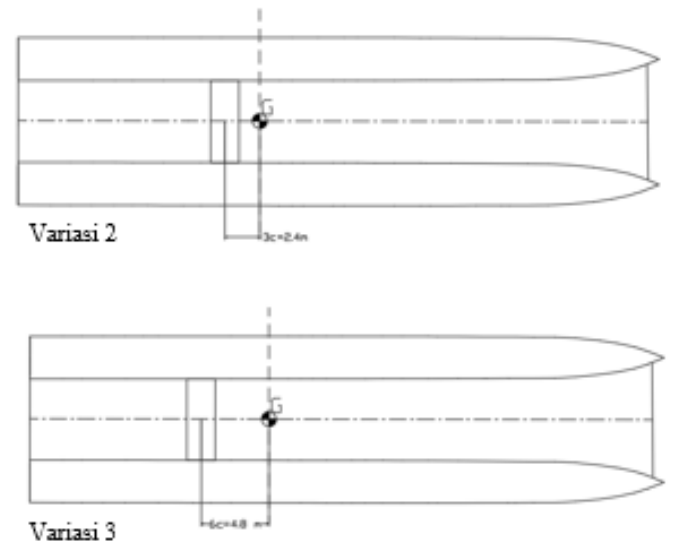

Gambar 5. Variasi Peletakan foil

\section{B. Meshing}

Pada tahap ini dilakukan pembuatan domain terlebih dahulu sebelum dillakukan proses meshing. . Ukuran domain memiliki standar ukuran boundary agar hasil analisa bisa sesuai dengan keadaan lingkungan sebenarnya. Ukuran domain yang digunakan dapat dilihat pada Gambar 6.

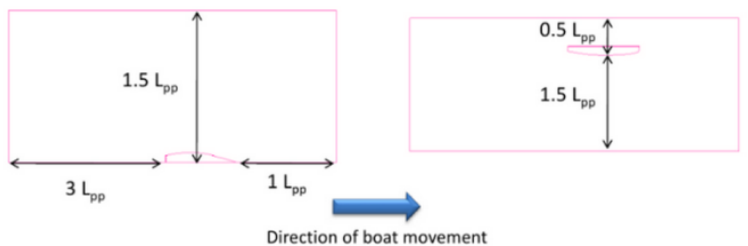

Gambar 6. Ukuran domain

Setelah dilakukan proses pembuatan domain ,tahapan selanjutntya adalah proses meshing. Proses meshing dilakukan dengan membagi geometri model ke dalam elemen-elemen kecil yang disebut cell. Hasil proses meshing dapat dilihat pada Gambar 7 dan Gambar 8. 


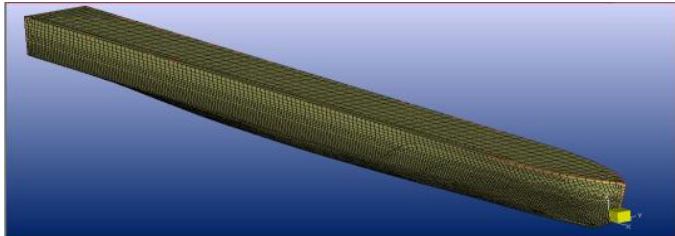

Gambar 7. mesh katamaran

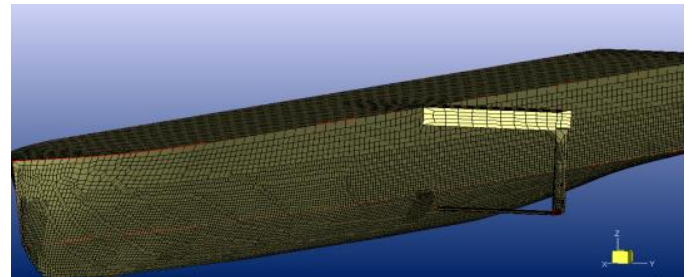

Gambar 8. mesh katamaran foil

\section{Proses Simulasi}

Setelah dilakukan proses meshing dan definisi geometri, tahapan selanjutnya dalah proses pengaturan parameter simulasi aliran. Kondisi aliran terbagi menjadi 2 jenis yaitu aliran steady dan aliran unsteady. Pada simulasi ini dilakukan pada kondisi aliran steady. Definisi fluida dibagi menjadi 2 bagian yaitu bagian fluida air laut dan fluida udara. Pada analisa ini bagian fluida dipisahkan oleh internal surface yang dibuat pada proses penggambaran geometri model. Model turbulensi aliran yang paling umum digunakan pada analisa aliran fluida adalah model k-omega (SST-Menter). Parameter ukuran kapal dan kecepatan kapal ditentukan untuk mendapatkan bilangan Reynolds dan bilangan Froude.

Batas domain perlu didefinisikan untuk membedakan jenis batas. Kondisi batas untuk badan kapal bisa berupa fungsi dinding yang memiliki definisi nilai gesek . Kondisi batas untuk bagian atas dan bawah domain didefinisikan sebagai fungsi tekanan hidrostatik. Kondisi batas untuk bagian depan, belakang, dan samping didefinisikan far field. Definisi bagianbagian domain yang merupakan bagian dari badan kapal dikelompokkan menjadi satu komponen. Kondisi gerakan kapal ditentukan. . Pada penelitian kali ini jenis gerakan kapal yang diaktifkan gerakan translasi pada sumbu x sedangkan gerakan kapal yang lain disetting dalam kondisi fixed. Parameter simulasi dapat dilihat pada Tabel 3.

Tabel 3 .

Parameter Simulasi

\begin{tabular}{ccc}
\hline \hline Deskripsi & Jenis & Kondisi \\
\hline Xmin (Inlet) & EXT & Far field , Vx $=0$ \\
Xmax (Outlet) & EXT & Far field, Vx $=0$ \\
Zmin (Bottom) & EXT & Updated \\
& & Hydrostatic \\
& & Pressure \\
Zmax(Top) & EXT & Updated \\
Hmin (Side) & Hydrostatic \\
Ymax(side) & EXT & Pressure \\
Ship and foil & SOL & Mirror \\
Deck & SOL & War field, Vx $=0$ \\
& & Wlip (zero shear \\
& Translation in X & stress) \\
Motion & direction & Velocity $=$ ship \\
& & using 1/2 \\
& & sinusoidal ramp \\
\hline \hline
\end{tabular}

\section{ANALISA DAN PEMBAHASAN}

Dari hasil simulasi CFD, maka didapatkan nilai hambatan total kapal katamaran. Perhitungan hambatan kapal katamaran dilakukan pada berbagai variasi kecepatan yaitu pada kecepatan 16, 20, 24, dan 28 knot. Selain menggunakan CFD, perhitungan hambatan katamaran dapat dilakukan dengan software Maxsurf Resistance dengan metode slender body. Perhitungan slender body mengasumsikan lambung kapal berbentuk simetris dan pipih dimana rasio antara panjang dan lebar kapal yang besar $\left(\mathrm{L} / \mathrm{V}^{1 / 3}>4.0\right)$. Berikut merupakan hasil simulasi nilai hambatan kapal katamaran pada berbagai variasi kecepatan dengan CFD dan Maxsurf .

\begin{tabular}{cccc}
\hline \hline Fn & Vs (knot) & CFD & Maxsurf \\
\hline 0,40 & 16 & 32,51 & 40,2 \\
0,50 & 20 & 65,83 & 71,8 \\
0,59 & 24 & 81,84 & 90,9 \\
0,69 & 28 & 99,8 & 110,6 \\
\hline \hline
\end{tabular}

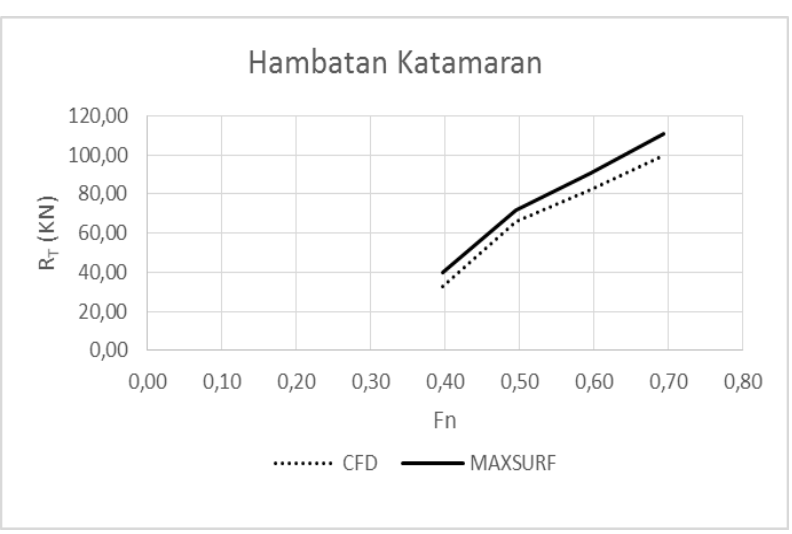

Gambar 9. Hambatan katamaran CFD dan Maxsurf

Gambar 9 menunjukan hambatan yang dihasilkan kapal katamaran dengan menggunakan Maxsurf Resistance dan CFD. Gambar 9 terlihat adanya perbedaan nilai hambatan yang dihasilkan CFD dengan Slender Body yang dilakukan Maxsurf. Nilai hambatan total yang dihasilkan oleh CFD lebih kecil dibandingkan dari hasil hambatan yang dihasilkan maxsurf.

Dari hasil simulasi didapatkan gaya angkat yang dihasilkan oleh foil. Besarnya gaya angkat foil yang tercipta akibat interaksi antara foil dengan demihull kapal.

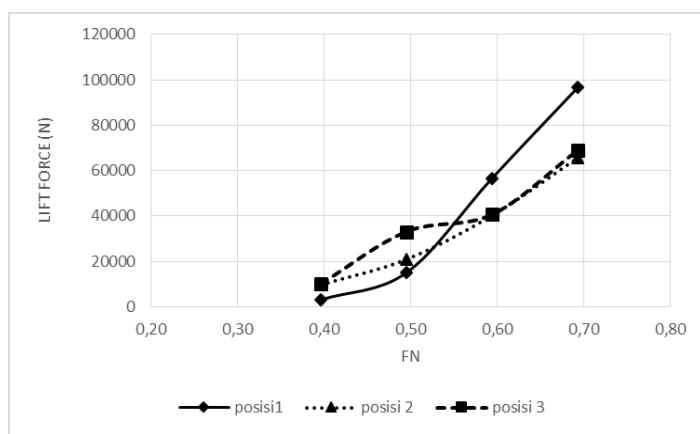

Gambar 10. Besarnya lift yang dihasilkan foil 
Gambar 10 menunjukkan hubungan antara besarnya kecepatan terhadap gaya angkat / lift force yang dihasilkan foil. Dari gambar grafik dapat diketahui semakin cepat kapal maka semakin besarnya gaya angkat yang dihasilkan oleh foil dan besarnya gaya angkat/ lift yang dihasilkan oleh foil pada posisi 1 yaitu di CG kapal lebih besar dibandingkan dengan posisi foil lainnya. Interaksi antara foil dengan badan kapal mengakibatkan gaya angkat yang dihasilkan oleh foil berkurang hal ini disebabkan karena tekanan rendah yang terjadi di permukaan atas foil menciptakan gaya isap kebawah (suction downward force) pada lambung kapal sehingga gaya angkat yang dihasilkan oleh foil berkurang [5].

Setelah mendapatkan gaya angkat yang dihasilkan foil, langkah selanjutnya dilakukan koreksi terhadap perubahan gaya angkat foil dan hambatan kapal terhadap perubahan displasement, luas permukaan basah, sarat kapal dan lwl. Pada kondisi ini kapal terangkat dalam kondisi even keel. Proses koreksi dilakukan dengan memasukkan displasemen kapal yang telah dikurangi dengan besarnya gaya angkat yang dihasilkan foil. Setelah dilakukan koreksi gaya angkat didapatkan nilai besarnya hambatan total kapal.

Tabel 4

Nilai Hambatan kapal setelah dikoreksi gaya angkat

\begin{tabular}{ccccc}
\hline \hline \multirow{2}{*}{ Fr } & \multicolumn{4}{c}{$\mathrm{R}_{\mathrm{T}}(\mathrm{kN})$} \\
\cline { 2 - 5 } & Barehull & Posisi 1 & Posisi2 & Posisi 3 \\
\hline 0,40 & 32,51 & 32,742 & 33,21 & 35,37 \\
0,50 & 65,83 & 62,926 & 64,48 & 61,642 \\
0,59 & 81,84 & 83,698 & 85,63 & 81,17 \\
0,69 & 99,8 & 65,018 & 82,252 & 78,654 \\
\hline \hline
\end{tabular}

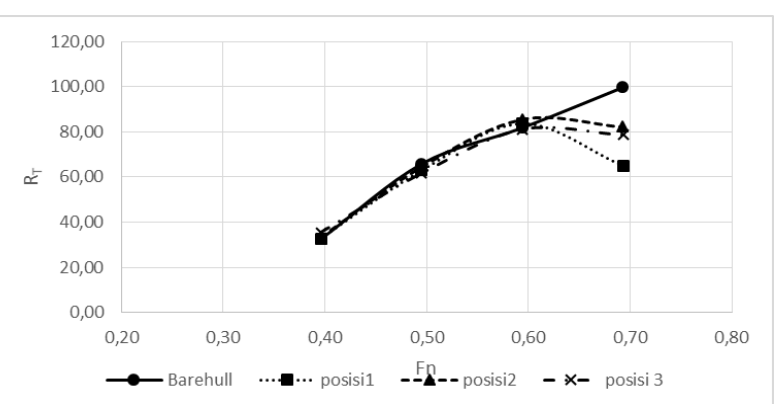

Gambar 11. Hambatan kapal setelah dikoreksi gaya angkat

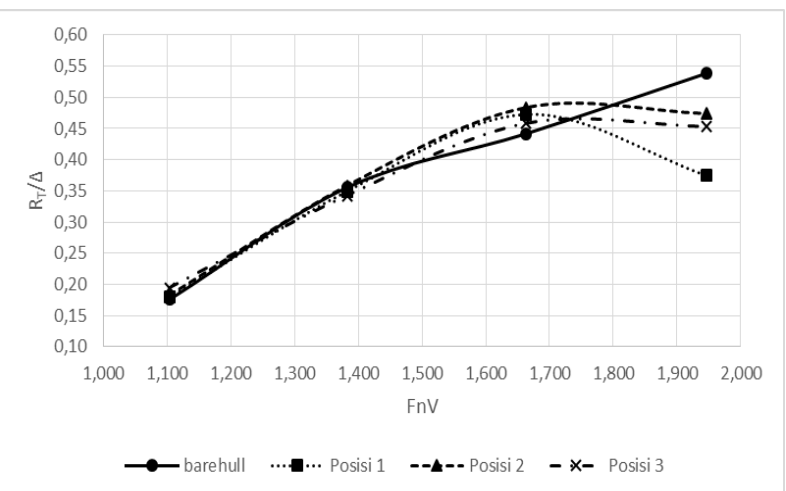

Gambar 12. Hubungan Hubungan RT/ $\Delta$ dengan FrV
Gambar 11 menunjukkan nilai hambatan kapal setelah dilakukan koreksi displasemen kapal. Pada Fn 0,69, nilai hambatan katamaran foil pada berbagai posisi mengalami penurunan. Hal ini terjadi kapal telah berada dalam fase transisi antara fase displasemen menuju planning dimana pada fase tersebut ditandai oleh pengurangan nilai hambatan yang disebabkan karena foil mulai mengangkat lambung kapal keluar dari air. Penurunan hambatan terbesar terjadi pada foil yang berada pada posisi 1 sebesar $35 \%$. Pada posisi 2 terjadi penurunan hambatan sebesar $18 \%$. Pada posisi 3 terjadi penurunan hambatan sebesar $21 \%$. Penurunan tren nilai hambatan pada bilangan $\mathrm{FnV}=1.955(\mathrm{Fn}=0,69)$ mirip dengan penelitian yang dilakukan (Loveday, 2006) dimana penurunan hambatan kapal dengan menggunakan Hydrofoil mulai terjadi pada bilangan $\mathrm{FnV}>2.0$ dimana pada saat itu foil mengangkat badan kapal keluar dari air akibat dominannya gaya hidrodinamika [6].

Tabel 5 Koefisien Hambatan

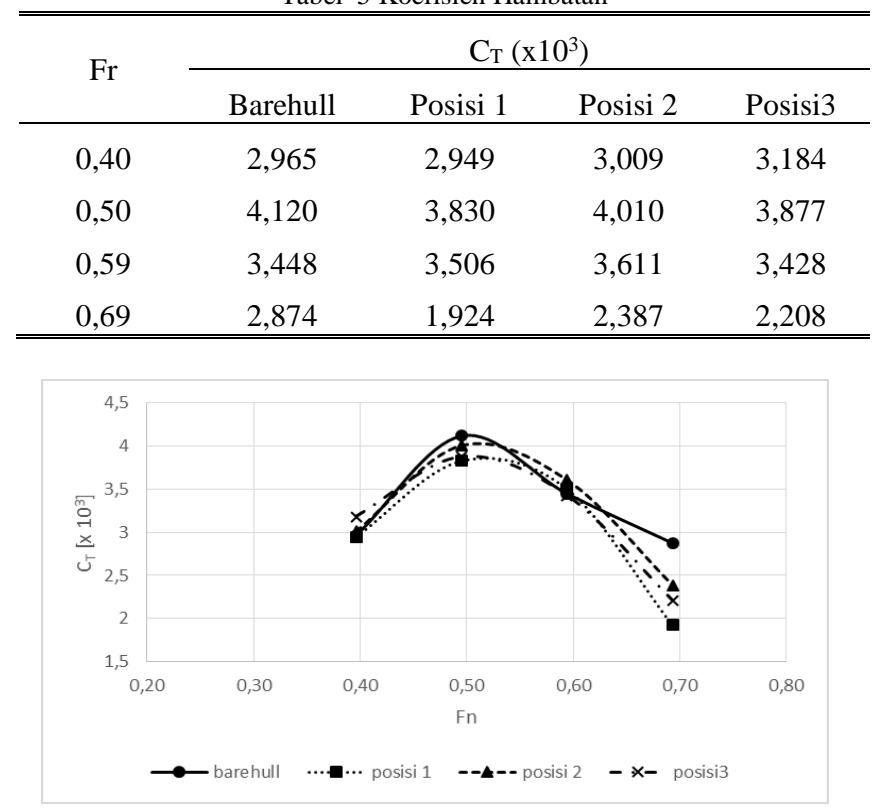

Gambar 13. Koefisien Hambatan

Gambar 13 menunjukkan nilai koefisien hambatan pada kecepatan rendah Fr 0,40 didapatkan nilai koefisien hambatan barehull lebih kecil dibandingkan dengan nilai koefisien hambatan kapal yang dipasang foil. Bertambahnya koefisien hambatan ini disebabkan pada kecepatan kecepatan rendah, foil menjadi appendages sehingga WSA kapal dengan foil lebih besar akibat penambahan foil yang tercelup kedalam air. Kemudian pada Fr 0,5 - 0,69 foil mulai mengangkat badan kapal keluar dari permukaan air sehingga WSA kapal dengan foil berkurang. Berkurangnya WSA kapal mempengaruhi besarnya hambatan kapal yang dihasilkan. Perubahan posisi foil secara memanjang berpengaruh terhadap hambatan yang dihasilkan. Nilai koefisien hambatan total awalnya meningkat mencapai nilai maksimum kemudian menurun seiring meningkatnya Fn. Fenomena tersebut disebut hump.Hump terjadi ketika 2 puncak gelombang bertemu pada waktu yang sama, sehingga timbul superposisi gelombang. Hump terjadi akibat pengaruh panjang dan kecepatan kapal, dimana 
keberadaanya ditimbulkan oleh sistem gelombang konvergen. Fenomena hump ini terjadi pada Fr 0,5 [6][7].

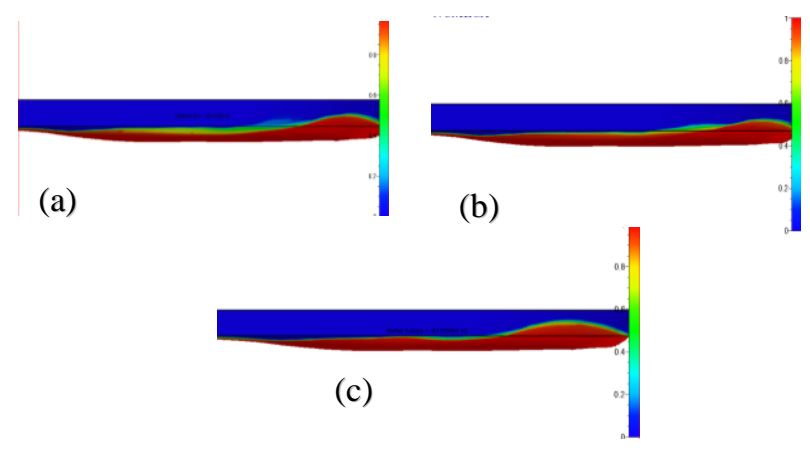

Gambar 14. WSA kapal, (a) posisi 1; (b) posisi 2; (c) posisi 3.

Gambar 14 menunjukkan luas permukaan basah kapal yang dialami model kapal katamaran foil pada berbagai posisi foil saat kecepatan 28 knot. Pada gambar ditampilkan perbedaan berdasarkan warna kontur dimana warna merah adalah daerah yang tercelup air dan warna biru adalah daerah udara. Dari gambar diketahui pada posisi 1 memiliki area yang tercelup lebih sedikit ini terlihat dari ketinggian garis air yang terjadi pada badan kapal lebih rendah dibandingkan dengan posisi foil lainnya. Pada posisi 3 terlihat jika area yang tercelup lebih banyak dibandingkan dengan posisi lainnya yang terlihat dari ketinggian garis air pada bagian haluan kapal. Perubahan posisi foil semakinke arah stern kapal mengakibatkan kapal menghasilkan momen gaya. Momen gaya itumengakibatkan bagian buritan kapal terangkat dan bagian haluan tercelup air. Hal ini berdampak terhadap WSA kapal yang meningkat.

\section{KESIMPULAN/RINGKASAN}

Berdasarkan analisa dan pembahasan yang telah dilakukan maka didapatkan kesimpulan sebagai berikut:

1. Hasil simulasi dengan foil menunjukkan ukuran foil yang paling optimum adalah dengan panjang chord $(c)=0,8 \mathrm{~m}$ serta span $=5,2 \mathrm{~m}$ (aspect ratio $=6,5)$. Selanjutnya sudut serang yang paling optimum adalah $2^{\circ}$ (dengan lift/drag ratio $=14,92$ ).

2. Lift yang dihasilkan oleh foil yang dipasang pada demihull lebih kecil jika dibandingkan dengan lift foil tanpa demihull. Penempatan foil secara memanjang berpengaruh terhadap gaya angkat yang dihasilkan oleh foil.

3. Pada kecepatan relatif rendah $(\mathrm{FnV}<1.8)$, foil menambah hambatan kapal sedangkan pada kecepatan relatif tinggi $(\mathrm{FnV}>1.8)$, foil mengurangi hambatan kapal.

4. Dari hasil simulasi dan analisa didapatkan hambatan kapal tanpa foil pada kecepatan dinas $(\mathrm{FnV}=1,955)$ sebesar 99,8 $\mathrm{kN}$ dan hambatan kapal dengan foil posisi 1(di bawah CG kapal) sebesar $65,018 \mathrm{kN}$, posisi 2 (3c di belakang posisi 1) sebesar $82,252 \mathrm{kN}$ ,dan posisi 3(6c di belakang posisi 1) sebesar 78,654 $\mathrm{kN}$.
5. Penggunaan hydrofoil pada kapal katamaran mengurangi hambatan kapal katamaran pada kecepatan dinas. Posisi peletakkan foil yang paling optimum (pengurangan hambatan terbesar) adalah peletakan foil posisi persis di bawah CG kapal (pengurangan hambatan sebesar 35\%).

6. Koefisien hambatan $\left(\mathrm{C}_{\mathrm{T}}\right)$ meningkat hingga mencapai nilai maksimum kemudian menurun seiring meningkatnya Fn. Nilai maksimum tejadi pada FnV $\approx 1.4(\mathrm{Fn} \approx 0.5)$

\section{UCAPAN TERIMA KASIH}

Penulis R.Y.D mengucapkan terima kasih kepada aktivano maulana sebagai teman diskusi dalam pengunaan CFD pada penelitian ini.

\section{DAFTAR PUSTAKA}

[1] A. F. Insel, M., \& Molland, "An investigation into the resistance components of high speed displacement," University of Southampton, 1990.

[2] K. Hoppe, Optimisation Of Hydrofoil Supported Planing Catamrns. Fast Sea Transportation, 1995.

[3] K. Migeotte, G., \& Hoppe, Developments in Hydrofoil Assistance for Semi-Displacement Catamarans. SNAME, 1999.

[4] C. Gibs, Hydrofoil Research Project for Office of Nacal Research Navy. Washington D.C, 1954.

[5] S. Ishikawa, Study on Hydrodynamic Interaction between Hull and submerged Foils. 1991.

[6] R. Marshall, Powering Your Boat. All About Powerboats: Understanding Design and Performance. New York: McGraw-Hill Professional, 2002.

[7] S. Suastika, K., Hidayat, A., \& Riyadi, "Effects of the application of a stern foil on ship resistance: A case study of an Orela crew boat," Int. J. Techonology, vol. 8, no. 7, pp. 1266-1275, 2017. 